\title{
OŚRODEK RENOWACJI DZIEL SZTUKI SAKRALNEJ (ORDSS). KONSERWACJA ZBIORÓW MUZEALNYCH I OBIEKTÓW KULTOWYCH
}

W ramach obchodów Jubileuszu 200-lecia Archidiecezji Lubelskiej, Metropolita Lubelski abp Józef Życiński podjął wiele cennych starań i inicjatyw celem stworzenia odpowiednich warunków lokalowych dla rozwoju działalności ekspozycyjno-konserwatorskiej muzeum archidiecezjalnego.

W okresie międzywojennym (od 6 III 1920 r.) pierwszym dyrektorem i założycielem muzeum był ks. Michał Niechaj, męczennik i więzień Zamku Lubelskiego, rozstrzelany przez hitlerowców 23 grudnia 1939 r. Mimo rozproszenia tych zbiorów, w ostatnim roku udało się odnaleźć kilka obiektów, które obecnie poddawane są zabiegom konserwatorskim i będą eksponowane w nowym Muzeum 200-lecia Archidiecezji Lubelskiej przy ul. Prymasa Wyszyńskiego 2, na górnych kondygnacjach kurii i pałacu biskupiego.

Nasze muzeum od ponownego go erygowania 26 VIII 1975 r. stworzyło profesjonalną pracownię konserwacji dzieł sztuki, dzięki której uratowano od zniszczenia wiele cennych muzealiów oraz przeprowadzono kompleksową konserwację zabytków sztuki sakralnej w wielu kościołach Archidiecezji Lubelskiej. Za zgodą Księdza Arcybiskupa obiekty wycofane z kultu, a pozostające jako własność lub depozyty w muzeum archidiecezjalnym często są przekazywane ponownie do kultu, po ich wcześniejszej pełnej konserwacji w naszych pracowniach. Muzeum przechowuje i zabezpiecza nie tylko zabytki sztuki religijnej, ale także pamiątki życia i kultury religijnej oraz przedmioty o treści świeckiej, pochodzące z kościołów i plebanii, pozostałe po księżach lub przekazane przez prywatnych ofiarodawców. Gromadzenie i eksponowanie dzieł tego rodzaju wskazuje na wielki udział duchowieństwa w tworzeniu i szerzeniu kultury rodzimej.

Muzealne pracownie konserwacji zabytków, z dniem 21 maja 2004 r. na mocy dekretu Arcybiskupa Metropolity Lubelskiego, otrzymały rangę Ośrodka Renowacji Dzieł Sztuki Sakralnej. Ośrodek przy ul. Filaretów 7 w Lublinie (przy dolnym kościele św. Józefa) prowadzi prace konserwatorskie zgodnie ze statutem i regulaminem zatwierdzonym przez biskupa diecezjalnego. Jego funkcjonowa- 
niem i finansami kieruje dyrektor mianowany przez Arcybiskupa Lubelskiego. Jednocześnie od dnia 21 maja 2004 r. dyrektorem ORDSS - pozostaje ks. Wojciech Szlachetka. Dyrektor ORDSS będący jednocześnie przewodniczącym Archidiecezjalnej Rady ds. Konserwacji Zabytków, wraz z Konserwatorem Dzieł Sztuki udzielają stosownych porad związanych $\mathrm{z}$ ochroną zabytków w terenie oraz służą konsultacjami w sprawie profilaktyki konserwatorskiej. Jednocześnie ORDSS uczestniczy we wspólnych pracach i komisjach konserwatorskich z udziałem Państwowych Służb Konserwatorskich. Działalność konserwatorska i naukowa opiera się także na współpracy i kontaktach dyrekcji z muzeami kościelnymi innych diecezji, oraz z pozostałymi muzeami Lublina. Szczególnie owocną działalność stanowi współpraca naszej placówki z pracownikami naukowymi Instytutu Historii Sztuki Katolickiego Uniwersytetu Lubelskiego, oraz z Ośrodkiem Archiwów, Bibliotek i Muzeów Kościelnych KUL. Od kilku już lat, $\mathrm{w}$ miesiącach wiosennych i letnich organizujemy praktyki studenckie w dziedzinie konserwacji dzieł sztuki.

\section{OCHRONA I KONSERWACJA ZABYTKÓW}

\section{Ratowanie i konserwacja obiektów zabytkowych}

Dotychczasowa specyfika Muzeum Archidiecezjalnego w Lublinie polegała na trosce i profilaktyce zmierzającej do zabezpieczenia najcenniejszych obiektów kultowych,, in situ" na terenie archidiecezji lubelskiej,w ich naturalnym środowisku.

Obecnie istotną rolę w ochronie i konserwacji zabytków spełnia Ośrodek Renowacji Dzieł Sztuki Sakralnej, wyposażony w sprzęt specjalistyczny i zajmujący się konserwacją malarstwa sztalugowego, malarstwa ściennego, rzeźby polichromowanej i złoconej (ołtarze, ambony, konfesjonały i chrzcielnice) oraz konserwacją mebli zabytkowych i sprzętów liturgicznych.

Metropolita Lubelski Ksiądz Arcybiskup Józef Życiński, mając na uwadze potrzebę opracowania kompetentnego programu z zakresu ochrony dzieł sztuki znajdujących się w posiadaniu kościołów w archidiecezji lubelskiej, powołał Archidiecezjalną Radę Konserwatorską ściśle współpracującą z Wojewódzką Służbą Ochrony Zabytków. Archidiecezjalna Rada Konserwatorska służy księżom-administratorom obiektów zabytkowych poradnictwem z zakresu ochrony zabytków i prawidłowych zasad konserwacji. Pośredniczy, także w staraniach o dofinansowywanie lub refundacje kosztów związanych z konserwacją zabytków z funduszy państwowych i samorządowych.Pracownicy ośrodka uczestniczą w wielu komisjach konserwatorskich oraz biorą udział w sesjach i szkoleniach w dziedzinie ochrony i konserwacji zabytków. Z inicjatywy Muzeum Archidiecezjalnego |w Lublinie i przy współpracy Kurii Metropolitalnej oraz z udziałem Wojewódzkiego Konserwatora Zabytków w lutym 2001 r. zorganizowano sesję naukową wraz ze szkoleniem pt. Conservatio-Renovatio-Rastauratio dla księży pracujących w zabytkowych kościołach na terenie archidiecezji lubelskiej. W sympo- 
zjum, któremu przewodniczył ks. abp Józef Życiński w auli Metropolitalnego Seminarium Duchownego w Lublinie, uczestniczyło ponad 170 księży, którzy wysłuchali wielu cennych referatów na temat prowadzenia prac konserwatorskich oraz zabezpieczenia obiektów przed kradzieżą, zniszczeniem i pożarem.

\section{Ochrona Zabytków Kościelnych}

Wszelkie prace konserwatorskie i renowacyjne, dla dobra dzieła sztuki zawsze powinny być prowadzone za wiedzą i zgodą konserwatorską Diecezjalnego i Wojewódzkiego Konserwatora Zabytków. Te dwa urzędy zapewniają nadzór nad prowadzonymi pracami oraz merytoryczną pomoc i radę, po to by lepiej rozumieć, jak skutecznie chronić skarby naszej kultury. We wspólnych pracach państwowych i kościelnych komisji konserwatorskich, najbardziej przykre są te sytuacje, kiedy ksiądz proboszcz z dumą oprowadzając po kościele, pokazuje i opowiada ile to udało się zrobić, mimo ogólnej biedy w parafii, a dla mnie jest oczywiste, że prace zostały wykonane źle, że za chwilę nie będzie już radości, lecz żal i poczucie krzywdy.

W ocenie wartości zabytków, a szczególnie zabytkowych świątyń i ich wyposażenia, istotna rolę odgrywa stopień zachowania ich autentycznej substancji, nawet gdy ona nam się nie podoba. Ta substancja głównie decyduje o wartości dokumentalnej kościoła i jego wnętrza. Właśnie dla historii Kościoła zabytki sztuki sakralnej są niejednokrotnie ważniejsze, niż dla historii sztuki.

Jakże często wchodzimy do zabytkowego kościoła i tam gdzie od wieków stał XVII-wieczny konfesjonał (najstarszy jaki mógł zaistnieć u nas) stoi nowy „mebel” wykonany przez miejscowych rzemieślników, w dodatku o prymitywnych formach nie pasujących do wnętrza. W innym przypadku widzimy w XVIwiecznym kościele, że dawną autentyczną posadzkę zamieniono na nową, błyszczącą i to jeszcze z kamienia obcego, który nigdy nie był stosowany w tym czasie na terenie naszego kraju i regionu.

Warto zwrócić uwagę, że zabytek gdy jest podniszczony i posiada tzw. patynę, robi na nas wrażenie, świadczy o jego dawności i autentyczności, przypomina o ludziach, którzy go ufundowali i przez lata tutaj przychodzili, klękali i modlili się.

Dla zrozumienia tych trudnych ale, jakże ważnych spraw dla historii Kościoła, Konferencja Episkopatu Polski już przed trzydziestu laty wydała specjalną instrukcję, która wyraźnie zaleca: „Duchowieństwo administrujące obiektami sztuki i kultury kościelnej niech pamięta, że zarządza własnością nie swoją, ale najwyższymi wartościami Bożymi i narodowymi, których całości i nienaruszalności winno strzec z największą troską i odpowiedzialnością przed Bogiem i Narodem."

Ojciec Święty Jan Paweł II uczył nas, przypominając słowa soborowej Konstytucji Duszpasterskiej Gaudium et spes: „Świat, w którym żyjemy potrzebuje piękna, aby nie pogrążyć się w rozpaczy. Piekno, podobnie jak prawda, budzi ra- 
dość w ludzkich serach i jest cennym owocem, który trwa mimo upływu czasu, tworzy więź między pokoleniami i łączy je w jednomyślnym podziwie!"

Jednym z wielu przejawów troski Pasterza Archidiecezji Lubelskiej o stan sztuki kościelnej, będącej zarazem skarbem kultury ogólnoludzkiej, było wydanie specjalnego dekretu w marcu 2003 r., w sprawie właściwej aranżacji wnętrz sakralnych z uwzględnieniem wymogów liturgicznych i artystycznych.

Wszelkie innowacje we wnętrzach kościelnych związane $\mathrm{z}$ nową aranżacją wystroju oraz zamierzenia konserwatorskie, winny być przed ich rozpoczęciem przedłożone do zatwierdzenia przez Kurialną Komisję Artystyczną. Natomiast w kontekście przygotowań do obchodów Jubileuszu 200-lecia diecezji lubelskiej celem zabezpieczenia i wytypowania najcenniejszych zabytków powołana została dekretem abpa Józefa Życińskiego z dnia 7 lipca 2003 r. Archidiecezjalna Rada do spraw zbiorów muzealnych.

\section{Dokonania pracowni konserwatorskich Ośrodka Renowacji Dzieł Sztuki:}

Posiadając profesjonalne pracownie konserwatorskie, dzięki doświadczonym i wyspecjalizowanym konserwatorom dzieł sztuki i pracownikom pomocniczym (laboranci i renowatorzy) uratowało przed zniszczeniem wiele cennych dzieł sztuki na terenie całej archidiecezji. Zespół konserwatorski (obecnie liczy 10 osób) wykonał kompleksową konserwację wielu dzieł sztuki w zakresie; malarstwa sztalugowego, malarstwa ściennego, rzeźby polichromowanej i złoconej, rzeźby kamiennej, detalu architektonicznego oraz zabytkowych mebli kościelnych i pałacowych. Dla potrzeb kilku kościołów w pracowni stolarsko-snycerskiej powstało wiele rekonstrukcji zabytkowych figur oraz kilka drewnianych i polichromownych rzeźb współczesnych i mebli kościelnych.

W latach 1992-2005 wykonano dla kościołów w archidiecezji pełną konserwację ponad 500 obiektów zabytkowych pozostających dalej w kulcie, oraz renowację wielu drobnych sprzętów rzemiosła arytystycznego, w tym:

- 166 obrazów olejnych na płótnie i desce,

- 34 ołtarzy głównych i bocznych

- 46 rzeźb drewnianych polichromowanych i złoconych,

- 62 sztuki mebli kościelnych (ławki, stalle, szafy, trony, konfesjonały i klęczniki)

- 18 ambon i chrzcielnic,

- 122 krosna i ramy do obrazów,

Dla wszystkich obiektów poddawanych konserwacji wykonano pełną dokumentację konserwatorską (opisowo-fotograficzną) po trzy egzemplarze dla każdego zabytku. Wykonano ponad 5000 sztuk fotografii barwnych, ilustrujących przebieg poszczególnych etapów prac konserwatorskich. Opis tych prac zajął 1350 stron maszynopisu.

Obiekty zabytkowe poddane konserwacji od ubiegłego roku 2004/2005:

- Stalle z obrazami przedstawiające żywot św. Brygidy (XVIII w.) w kościele powizytkowskim w Lublinie przy ul. Narutowicza 6. 
- Ołtarz główny (XVIII w.) w kościele parafialnym w Dzierzkowicach wraz z obrazami św. Stanisława i Marii Magdaleny.

- Ołtarz główny z obrazami (początek XVII w.) z kościoła św. Wojciecha na Podwalu w Lublinie.

- Struktura ołtarza i złocone tabernakulum w kościele parafialnym w Rudnie.

- Kilka obrazów olejnych na płótnie z kościołów w: Baranowie, Dąbrowicy, Czerniejowie, Kraczewicach, Kijanach, Markuszowie, Rybitwach i Rudnie.

Ambona w kościele Ewangelicko-Augsburskim w Lublinie.

Cieszy fakt, że już od ubiegłego roku większą troskę mogliśmy poświęcić konserwacji własnych zbiorów zgromadzonych przed wielu laty w magazynach.

W bliskiej perspektywie pozostaje otwarcie nowej ekspozycji malarstwa, rzeźby, i rzemiosła artystycznego w organizowanym Muzeum 200-lecia Archidiecezji Lubelskiej.

Dla tej ekspozycji prowadzimy konserwację najcenniejszych muzealiów, dzięki pozyskanym funduszom celowym z dotacji Unii Europejskiej. Pełna konserwacja obejmuje;

- 22 obrazy olejne na płótnie i 2 ikony na desce,

- 10 rzeźb drewnianych polichromowanych i złoconych,

- 14 zabytkowych mebli,

- 18 sprzętów rzemiosła artystycznego,

- 8 zabytkowych szat liturgicznych,

Udostępnienie ekspozycji dla zwiedzających nastąpi wraz z otwarciem Muzeum 200-lecia Archidiecezji Lubelskiej, jesienią 2006 r.

\section{Zakończenie}

Cel i zadania Muzeum Diecezjalnego w sposób szczegółowy określa, uchwalony przez Konferencję Episkopatu Polski w dniu 18 listopada 1976 r., Statut Muzeum Diecezjalnego. Podstawę prawną Muzeum Diecezjalnego stanowią: Kodeks Prawa Kanonicznego, Konstytucja o Świętej Liturgii Soboru Watykańskiego II, Okólnik Kongregacji do Spraw Duchowieństwa- w trosce o zachowanie artystycznego i historycznego dziedzictwa Kościoła z dnia 11 kwietnia 1971 r., oraz Normy Postępowania w Sprawach Sztuki Kościelnej, uchwalone przez Konferencje Episkopatu Polski dnia 25 stycznia 1973 r. Konferencja Episkopatu Polski postanowiła, aby każda diecezja posiadała własne Muzeum Diecezjalne. Muzeum eryguje biskup- ordynariusz diecezji, utrzymuje je i sprawuje nad nim nadzór. „Dzieła sztuki zasadniczo powinny pozostawać w aktualnym kulcie w kościołach, kaplicach i stanowić wyposażenie pomieszczeń kościelnych. Jeśli nie mogą już spełniać tego zadania, a w razie pozostawienia ich na miejscu, będą narażone na zniszczenie lub kradzież, należy je przekazać do Muzeum Diecezjalnego.”

Ośrodek czynny jest codziennie w godz. 8-15; tel. (081) 444-74-50. 


\section{BIBLIOGRAFIA :}

Archidiecezja Lubelska. Historia i administracja, red. Marek T. Zahajkiewicz, Lublin 2000.

Archidiecezja Lubelska. Informator, Lublin 1995.

B. Pylak, Biskup Lubelski Stefan Wyszyński jako duszpasterz, Lublin,1996.

M. T. Zahajkiewicz, Diecezja Lubelska. Informator historyczny i administracyjny, Lublin1985,s.4

Informator. Muzeum Diecezjalne Sztuki Religijnej, opr. Jerzy Mleczek, Lublin 1991.

„Informator Lubelski”, maj-sierpień 1996, nr 1.

Kronika Muzeum Diecezjalnego lata 1975-1992.

Kronika Muzeum Archidiecezjalnego; lata 1992-2002.

„L'Oservatore Romano”, 5-6/1999.

Muzeum Diecezjalne Sztuki Religijnej, Lublin 1985.

II Synod Diecezji Lubelskiej, Lublin 1988.

„Wiadomości Diecezjalne Lubelskie”, 10-12 (1976). 